\title{
LEITURAS OUTRAS: UM ENSAIO PARA (RE)PENSAR \\ A ESCRITA E A LEITURA À LUZ DE ROLAND BARTHES
}

\author{
OTHER READINGS: AN ESSAY TO (RE)THINK THE WRITING
}

AND READING IN THE LIGHT OF ROLAND BARTHES

\section{Edilaine Vieira Lopes', Cleber Gibbon Ratto²}

\author{
Recebido em: 10 de junho de 2017 \\ Aprovado em: 30 de outubro de 2017 \\ Sistema de Avaliação: Double Blind Review \\ RCO | a. 10 | v. 1 | p. 27-38 | jan./jun. 2018 \\ DOI: https://doi.org/10.25112/rco.vli0.1321
}

\begin{abstract}
RESUMO
O presente texto apresenta-se como articulador das principais discussões desenvolvidas na dissertação de mestrado intitulada "Será tão difícil escrever? Ensaio entre a escrita e a escritura: contribuições de Roland Barthes à educação" (2011). Explora a problemática e a concepção de que a leitura, se for atrelada à escritura, pode ser uma potência, fruto de iniciação, uma aventura com generalidade simbólica ligada ao prazer. Ao modo de um ensaio teórico, divide-se em quatro partes: a) $1^{\circ}$ gesto, a escrita; b) $2^{\circ}$ gesto, a leitura; c) $3^{\circ}$ gesto, o prazer envolvido; d) $4^{\circ}$ gesto, leituras outras. Desenvolve a tese segundo os preceitos de Roland Barthes (1915/1980), com base no grau zero da escrita. Sustenta a importância da escola dar vez à fruição, ao devir e ao ócio criativo, em contrapartida aos exaustivos trabalhos sobre o desenvolvimento da escrita/leitura, que parecem ignorar a aparente ligação que há entre a leitura, a escritura e a vida, através de uma relação em que o escritor/leitor deixa de ter apenas autoria do texto, abrindo mão de ser o autor/usuário e passando a ser usado pela linguagem (em vez de apenas usá-la), de modo corajoso, considerando o outro que está necessariamente imbricado nos discursos que nos constituem diariamente.
\end{abstract}

Palavras-chave: Leitura. Escrita. Cultura. Roland Barthes.

\section{ABSTRACT}

The current text is presented as an articulator of the main discussions developed in the Master's thesis entitled "Is it so hard to write? Essay between writing and essay writing: contributions from Roland Barthes to Education" (2011). It explores the problematic and the conception that reading, if attached to writing, can be an output, fruit of initiation, an adventure with symbolic generality related to pleasure. In a theoretical essay mode, it's divided into four parts: a) first gesture, the writing; b) 2nd gesture, the reading; c) 3rd gesture, the pleasure involved; d) 4th gesture, other readings. It develops the thesis according to the precepts of Roland Barthes (1915/1980), based on the degree of zero writing. It sustains the importance of the school to give time to fruition, to the future and creative idleness, in contrast to the exhaustive work on the development of reading/writing that seems to ignore the apparent link between reading, writing and life through a relationship in which the writer/reader doesn't only have the authorship of the text giving up of being the author/user and starting to be used by the language (instead of just using it) bravely, considering the other that is necessarily interwoven in the speeches that form us daily.

Keywords: Reading. Writing. Culture. Roland Barthes.

\footnotetext{
${ }^{1}$ Doutora em Letras pelo Centro Universitário Ritter dos Reis (Porto Alegre/Brasil). E-mail: edilaine.nh@ gmail.com.

2 Doutor em Educação pela Pontifícia Universidade Católica do Rio Grande do Sul (Porto Alegre/Brasil). Professor na Universidade LaSalle (Canoas/Brasil). E-mail: cleber.ratto@unilasalle.edu.br.
} 


\title{
INTRODUÇÃO
}

O presente artigo apresenta-se na forma de um ensaio teórico, que articula as principais discussões desenvolvidas na dissertação de mestrado intitulada "Será tão difícil escrever? Ensaio entre a escrita e a escritura: contribuições de Roland Barthes à educação" (2011). Toma-se como argumento central a concepção de que a leitura, se for atrelada à escritura, pode ser uma potência, fruto de iniciação, mas também o grau zero da escrita, uma aventura com generalidade simbólica, mais ligada ao prazer, à fruição, ao devir e ao ócio criativo, em contrapartida aos exaustivos trabalhos sobre o desenvolvimento da escrita/leitura, que parecem ignorar a aparente ligação que há entre a leitura, a escritura e a vida, através de uma relação em que o escritor/leitor deixa de ter apenas autoria do texto, abrindo mão de ser o autor/usuário e passando a ser usado pela linguagem (em vez de apenas usá-la).

Roland Barthes (1915/1980) foi um escritor, sociólogo, crítico literário, semiólogo e filósofo francês. Fez parte da escola estruturalista, influenciado por Saussure. Conhecido por inovar com seus termos utilizados para descrever diferentes formas de pensar sobre o criador e o texto, são exemplos: autor, que escreve e tem autoria, insigths e escritor (que se faz e renasce na sua escritura). Defendia em seus livros que a escrita se fundamenta em textos anteriores, reescrituras, normas e convenções. Conforme Bocca (2017):

\begin{abstract}
Barthes, como vimos, substituiu o pólo da permanência pelo pólo do devir, o que não caracterizou uma simples e ingênua negação do estruturalismo. Apenas abandona a pesquisa das formas ou modelos explicativos dos fatos humanos, passando a reconhecer e privilegiar a historicidade da investigação que, na nova perspectiva, coloca-se permanentemente em marcha. Nosso autor afirma com sua atitude a possibilidade de que, por atos de "invenção", significados sejam permanentemente elaborados (p.26).
\end{abstract}

Assim, Barthes satirizava toda importância dada à biografia do autor, excessiva se comparada à escassez quanto ao escritor. Afirmava que a morte do autor era o nascimento do leitor. Dada a sua importância, passou por uma virada em sua teoria: em determinado momento em sua vida, passou a perceber que a tarefa dos estruturalistas em homogeneizar e categorizar as coisas era exaustiva. Deixou de fazer isso com seu objeto de estudo, o texto, revolucionando a linguística frasal. Um estudioso que levava em consideração o sujeito e a sua história.

A escolha pelo ensaio, como forma, método e estilo, se sustenta com base em Larrosa (2004), tendo em vista que é um dos gêneros mais fundamentais da modernidade e atende ao propósito de produzir escritas experimentais e enunciados a partir de diferentes experimentações sobre o ensino da língua escrita, a partir da prática docente cotidiana. Logo, esse artigo se constrói desse modo por ser, acredita-se, mais favorável à escritura, no sentido atribuído por Roland Barthes.

\section{PRIMEIRO GESTO - SOBRE A ESCRITA}

Sempre me preocupei com a escrita ${ }^{3}$, com os modos de escrever, de aprender, tentando diminuir a angústia dos que demonstravam insegurança, pois queria ajudá-los. No mínimo, retribuiria o que fizeram por mim na matemática. Não que eu fosse muito mal, mas não era minha praia. Admiro a física, as fórmulas. Reconheço, com uma ponta de inveja, a beleza dos números e das suas combinações. Sei

\footnotetext{
${ }^{3}$ A partir da leitura das obras de Roland Barthes (1915- 1980), sobretudo das três principais (O rumor da língua, 2004; O prazer do texto, 2002; O grau zero da escrita, 2004), entende-se por "escrita" o processo formal, que é ensinado nas escolas e valorizado na sociedade grafocêntrica em que vivemos, na qual a norma dita "culta", gramatical, é prestigiada e onde só se dá bem, só tem emprego e salário garantidos, trabalhos promissores, quem souber fazer uso da língua, isso é, "escrever bem", usar a linguagem para obter prêmios, notoriedade social, acadêmica e intelectual, lucros, a seu bel prazer.
} 
que este encanto nem sempre é possível para todos nas Letras, tão sem graça, paradinhas, preocupadas com a forma.

Como educadora, me angustia ver alunos com parecer e diagnóstico médico, quase justificando sua incapacidade cognitiva para a escritura. Acho que há casos e casos. Sei de muitas limitações, mas não há limites para a arte, para a criação, para o prazer da fruição, quando as coisas estão imbricadas e, juntas, formam uma coisa só. Essa implicação é utopia minha, ou talvez não. Mas é ela que eu busco quando atrelo a escritura à minha vida, ao prazer, à dor, à vida e à morte. E é essa constante, é esse processo doloroso e prazeroso, esta mistura de gozo e suicídio, que me encanta. Dissertei sobre isso, não como dona da verdade ou sabedora e detentora da escrita: como opção e invenção. Mas minha tese não permite um ensaio inventivo, opcional.

Sempre fui considerada a "boa aluna", que não questiona, não cria problemas. A que resolve. Faz os temas, fica quieta durante a aula. Capricha. Cria. Vai além. Tudo comigo sempre tentou ser perfeito e, se não era, estava a caminho, tentando chegar lá. A exceção era a letra, que não negava minha personalidade e dava indícios de que um dia eu ia me rebelar. Quem mandou ler Machado de Assis? Aprendi o estilo e o recurso de usar um repertório com ironia. Também não nego que perdi a modéstia quando descobri Schopenhauer e seus estratagemas. Vi que meu pessimismo não passava de realismo, ao ler um pouco de Nietzsche.

Com Barthes, me libertei das rédeas da escrita e descobri o que estava tentando fazer com meus alunos: escrita, embora tenha tido professores que, por pura intuição, fizeram a escritura ${ }^{4} \mathrm{e}$ me iniciaram neste caminho. Por que deu certo para mim e não para os outros, ou só para uns, não para todos? Não sei, nem pretendo salvar o mundo com minhas teorias. Se ainda tivesse uma, seria ótimo. Não, não quero cair no niilismo. Relativismo não "cola" mais... eu sei. O que desejo? Talvez explicar a mim mesma, a mais interessada no assunto, minha relação e minhas descobertas com a criação da escritura. Escrever nunca foi difícil para mim, mas por quê?

Com Virgínia Kastrupp (2009) e Jorge Larrosa (2004) percebi que, num dado ponto, parei de resolver problemas e de ser considerada aluna inteligente. Agora sou "a burra"? Não sei, mas sou vista com outros olhos, sou diferente... Metida, jovem sonhadora que quer mudar o mundo, exibida, quero me meter onde não devo, mexer com o que já está dado por certo, por vencido pela razão. Então percebi que é mesmo mais excitante criar problemas, querer fazer diferente, de outro modo, usando perguntas, não só respostas. Talvez por isso é fácil escrever, porque eu não tenho a pretensão de que seja nem fácil, nem difícil. Só preciso fazer, escrever, tentar, obedecer as letras que querem sair de dentro de mim, pois eu sou o mundo, o mundo é ... opa! O mundo sou eu! Eumundo; mundoeu. A linguagem faz o mundo e me refaz; o mundo só existe pela linguagem, logo, por mim, por nós; isso é tudo o que se tem, cabe a mim aceitar e criar novos problemas, questionar, tentar aprender com isso, aprender comigo, com o mundo, com a linguagem, visto que somos $\mathrm{UNO}^{5}$.

De vez em quando, me refugio na literatura. Garimpo o mundo com o Palomar, de Calvino, ou me derreto com o amor quase Quixotesco de Inês Pedrosa, a Jenny, uma Dulcineia às avessas. Me divirto com Rubem Alves, em "Pensamentos que penso quando não estou pensando" e reviro o Baú de Espantos do bom e velho Quintana. Umas vezes corro para a Cecília, em outras fujo com Vinícius. Descubro,

\footnotetext{
${ }^{4}$ Em "O rumor da língua”, Barthes (2004, p.382) afirma que a escritura é uma potência, fruto de iniciação, mas também o grau zero da escrita, uma aventura com generalidade simbólica.. Entende-se que a escritura está mais ligada ao prazer, à fruição, ao devir, ao ócio criativo, do que propriamente, aos exaustivos trabalhos de ensaio da escrita acadêmica, tanto treinados na escola formal.

${ }^{5}$ Nossa expressão, remetendo ao conceito de alteridade com base na arquitetônica das obras de Mikhail Bakhtin, no sentido de que só o outro nos completa; só somos um quando, de fato, admitimos que temos o outro em nós.
} 
nesse meio tempo, que "Amor é prosa e sexo é poesia"... grande Jabor! Vou do Zahir ao Aleph, com Coelho, me ofendo com Assis, chamando-me de leitora desgraçada e me mandando ler direito! Aí que surge a pedra... no meio do caminho. Mas Drummond não pode me ajudar, nem Pessoa, que tenta me explicar que devo guardar as pedras e montar meus castelos. Camões só me incentiva a seguir navegando e, então, percebo que não posso escrever literatura agora. Afinal, ninguém entenderia! Mas quem vai me entender assim mesmo, desse jeito? Um ensaio talvez me dê a noção de falsa liberdade, por haver a possibilidade de ter um texto único, não cortado, tampouco fragmentado, como frango no abate, separado em miúdos, coxa, peito, vísceras... É, talvez.

A única garantia que tenho é a de que ainda estou respirando, pelo menos enquanto escrevo essas frases, que nada mais são do que versos. Antes, tentei fazer poesia, mas fiz prosa. Agora é o inverso: escrevo prosa, mas só sai poesia. Minha certeza é só uma, a de que um dia vou morrer. Se tiver sorte, quando isso ocorrer, pode ser que já tenha uma dúzia de respostas para minhas perguntas antigas e umas centenas de outras novas questões em aberto. Se escrevo, de fato, bem? Não sei. Dizem que flui. Particularmente, sou muito chata, crítica com o que partilho. Quando escrevo, me dispo, não é fácil ficar assim, nua. Ainda mais quando pretendo deixar que me avaliem, serei avaliada. Numa banca, em geral, o devir nunca é bem aceito, bem quisto, destarte na Letras não seria diferente... Ai, que pena. É ali que devia haver criação, diferença. Unidade plural. "Mas isso é impossível?!", não, não é. Se posso dizer que há "pôr-do-sol", mesmo sabendo que o astro nem se move, fica lá, paradinho, então posso criar palavras, usá-las como quiser, jogar fora e nem dar satisfação a ninguém. E, assim, todos ficam felizes, achando que se comunicam bem e que se entendem. E, então, o mundo vive sem guerras! John Lennon não está mais aqui para criar canções de paz... Nem precisa!

Com a escrita, compreendi que no embate com a gente ou com o mundo, tendemos a preferir o mundo. Me empolguei com a reportagem da revista Língua Portuguesa, que incentivava a criação de teses e dissertações literárias. Se tudo é convenção, invenção ${ }^{6}$, se tudo são só acordos, palavras, união de letrinhas, ficção por ficção, prefiro a literatura! Mas o ensaio supre minhas necessidades pontuais... É uma emergência. Preciso criar este problema, agora! Por enquanto, está bom. Ficarei bem assim. Eu acho!

Segui com dúvidas e prossegui com os estudos na pós-graduação. Não sei se tenho as respostas, nem se pretendo achá-las, mas penso que escritura, vida e criação são unidades plurais, isto é, são coisas separadas (unidades), mas ficam interligadas, por meio de redes repletas de significados e de sentidos (plurais), ou seja, por meio da leitura. Se escrever é ensaiar a vida, então se justifica bem, sob tal ótica, a escolha pelo ensaio crítico. Tal ironia do destino foi a de eu me interessar pelo tema, mas estar presa à forma como desenvolveria minha própria criação ${ }^{7}$, a tese, conectada fortemente ao modo como deveria

\footnotetext{
${ }^{6}$ A palavra invenção será muitas vezes aqui repetida, tendo em vista que este trabalho bebe na fonte da teoria de KASTRUP (1999), que vê a cognição como a invenção de problemas, não apenas como solução ou resolução. Na obra "A invenção de si e do mundo", Kastrup (1999, p. 27) difere a cognição, como inteligência artificial, advém da psicologia, filosofia e neurociência, da cognição considerada quando se cria algum problema, decidindo atribuir uma nova direção, novas formas de pensar e fazer. $\mathrm{Na}$ atualidade, a invenção tem lugar. Fazer história da atualidade não é fazer sobre o que se passou, mas sobre o que está se passando, de um movimento. Partir de um devir, de uma experimentação difícil de avaliar em suas consequências para a história. INVENIRE, do latim, significa encontrar relíquias ou restos arqueológicos. = invenção. O resultado é necessariamente imprevisível. A invenção implica o tempo. Ela não se faz contra a memória, mas com a memória, como indica a raiz comum à "invenção" e "inventário".

${ }^{7}$ Criar aqui é entendido como um vir a ser e fica, também, atrelado à obra de Kastrup (1999, p. 20), que com sua tese percebeu que o DEVIR CRIATIVO também é tema da cognição, "misteriosa potência capaz de nos lançar para além da mera aquisição de conhecimento, na dimensão transversal, enquanto o conceito de cognição é aqui intensificado e expandido por um tratamento especial de dois componentes que passam a reativar sua compreensão como potência interrogativa. Componentes: o primeiro deles consiste em privilegiar a criação, a invenção, a constituição de problemas. Politizar, por exemplo, vem a ser muito mais que mera colagem de palavras de ordem verborragias ideológicas. O segundo indica a importância de evitar que o movimento
} 
escrever, qual estilo teria mais ou menos prestígio? Estava engessada. Faria greve. Pela primeira vez, estava com dificuldades para escrever. Mal sabia eu que o problema todo era a minha relação com a escrita, que engessa. Foi, então, que me dei conta do papel da leitura.

\section{SEGUNDO GESTO - SOBRE A LEITURA}

Por que estou fazendo todo esse discurso introdutório que me traz de volta ao passado? Para compreender minha trajetória de vida com a pesquisa, com as letras e com a leitura, já que na escola mudamos o discurso ao "ensinar" aos alunos que se trabalha na perspectiva dos gêneros textuais e de tipologias. Não é mais como aprendíamos: isto é narração, isto é descrição. Tudo anda junto. Não se faz mais "Ivo viu a uva", por se ter percebido que é na unidade do texto e na sua relação de sentido com as coisas e com o mundo que a mágica da linguagem perpassa e se faz, nos constitui enquanto seres que pensam e que se comunicam. Mesmo assim, ainda há nos livros didáticos, vulgo "os melhores e altamente recomendáveis", passos sobre como desenvolver um bom texto, como resolver o problema da escrita, da forma, do estilo, da estética, do objeto por ele mesmo, com um determinado fim.

Assim, como num texto preparado por meses num curso de pré-vestibular, desses bem caros, empilhados aos montes nas capitais, dividido em partes (introdução, desenvolvimento, problema, clímax, resolução), a metaescrita, que usei em forma de texto, visando à escritura, obedeceu rigorosamente os planos de aula, para ouvir, sentir, vivenciar e presenciar o rumor vivo da língua ${ }^{8}$. Pela oportunidade que tive ao relatar o projeto inicial e observar meus alunos, além de vivenciar minha própria escrita, pude compreender o que os teóricos afirmavam, que escrever se torna difícil quando não há lugar para a escritura, para aquilo que faz sentido, quando o corpo e as intensidades estão fora da jogada, uma vez que a escritura passa pela nossa vida e nossa vida passa pela escritura, já que tudo é linguagem.

Arrisco dizer que é preciso estudar melhor essa relação entre a leitura e a escritura, processos necessários e prazerosos, que parecem ter sido esquecidos na educação. Mas não a leitura como promoção, como um "ler para escrever e falar melhor": a leitura como um dar a ler, como fruição, prazer, gozo. Para isso, não buscarei o leitor ideal, nem o maior e melhor romance, a narrativa premiada com o Nobel. Pelo contrário, quero o incomum: o leitor em processo ou que ainda não construiu, como eu conseguira na infância, o hábito de ler. Mas não falo aqui de um "ler poético, literário, apenas". Falo, agora, de leituras outras, como práticas, como gêneros discursivos e não somente textuais.

A leitura atenta, orientada em aula, parece ser um bom recurso para alertar contra os perigos e consequências da crise ecológica gerada pelo modo capitalista de produção e/ou o texto que melhor aporte e analise propostas de soluções anticapitalistas. Parece permitir o reconhecimento e a difusão do pensamento crítico sobre as problemáticas e desafios do mundo contemporâneo a partir das perspectivas

inventivo da cognição se fragilize no mero culto ou cultivo dos problemas. Cognição criativa leva em conta não só a invenção de problemas, mas também a constituição de linhas de solução, de formações discursivas (ou não), que lhes sejam favoráveis, de dispositivos complexos. Invenção: é possível escutar tal silêncio, pois se trata da atualidade: invenção como um problema. O problema da invenção é colocado por nossa atualidade discursiva, ser e devir, invenção e estudos da subjetividade, invenção de novas possibilidades, novas formas de existência. Falso problema: a criação não se encontra a serviço de problemas já dados, que são, em última análise, os da sociedade, principalmente da sociedade americana. A função de criação não é situada como própria de uma tendência que difere em natureza da tendência intelectual, não é uma linha divergente em relação à inteligência". ${ }^{8}$ Barthes (2004, p.93) questiona se "a língua, pode rumorejar?" Para ele, como palavra, ela permanece condenada ao balbucio. Já em forma de escrita, ao silêncio e à distinção dos signos; mas, ele insiste, fica ainda para que a linguagem realize um gozo que seria próprio da matéria. Mas o que é impossível não é inconcebível: o rumor da língua forma uma utopia". Porém não com relação à identidade entre as coisas, as palavras. Fala-se do funcionamento, do encaixe, do barulho, dos ruídos da língua, da sintonia que há entre a linguagem e a vida, daí a explicação da escritura estar ligada à vida. Rumorejar seria fazer ouvir a própria evaporação do barulho: o tênue, o camuflado, o fremente são recebidos como sinais de uma anulação sonora. 
de amplo sentido anticolonialista, anti-imperialista e emancipatório. Assim, Ler ainda representa o ato de Ensaiar, para Pensar Contra a Corrente, thinking out the box... Como uma alternativa ao silenciamento e à marginalização que afetam o pensamento emancipatório nos circuitos da reprodução hegemônica e da dominação social e intelectual, visando a contribuir para o desenvolvimento de ideias, análises e propostas ativas na área da cultura.

A pergunta é: será que "só" ler será eficaz no combate ao analfabetismo funcional? Não. Deve estar, como ato, atrelado ao escrever e, melhor, ao hábito de reescrever sua história (escritura social). A literatura é potente auxiliadora no processo de igualdade (combatendo a desigualdade social). Deve começar antes, em casa, não só nas escolas. Não defendo a bandeira de assumir somente as identidades contemporâneas, nem deixar de lado o status social que a leitura ${ }^{9}$ de romances e clássicos tem.

É preciso investigar, quantificar, acompanhar, coletar e analisar dados para podermos afirmar, não apenas empiricamente, a ideia que acabar com o ctrC+ctrV pode ser um potente instrumento pedagógico de auxílio e desenvolvimento à leitura ${ }^{10}$. Mas aí falamos em outros termos: à introdução à pesquisa, contribuindo, portanto, com o desenvolvimento de cidadãos conscientes do poder da autonomia e do protagonismo juvenil, despertado facilmente pelo poder da leitura rumo à produção de conhecimento em meio a essa sociedade bombardeada por informações.

Parece necessário discorrer sobre os processos de "leitura e escrita" (como algo informal, diferente do ensinado nas escolas e valorizado na sociedade grafocêntrica em que vivemos) e de "leitura e escritura", que parecem ser diferentes e que, portanto, produzem diferentes efeitos na prática cotidiana de ensino/ aprendizagem da língua. Como hipóteses, penso que a leitura abordada de modo a um "dar a ler" tende a desbloquear o caminho da escritura e permitir que todos saiam da inércia, da forma da escrita maçante ensinada nas escolas, ainda (e falo com propriedade, por ser educadora).

Leitura e escritura parecem ser processos diferentes e, portanto, produzem diferentes efeitos na prática cotidiana de ensino/ aprendizagem da língua. Percebe-se que a leitura, atrelada à escritura, é uma potência, fruto de iniciação, mas também o grau zero da escrita, uma aventura com generalidade simbólica, mais ligada ao prazer, à fruição, ao devir e ao ócio criativo do que, propriamente, aos exaustivos trabalhos de desenvolvimento da escrita/ leitura. Logo, parece haver ligação entre a leitura, a escritura e a vida, através de uma relação em que o escritor/leitor deixa de ter apenas autoria do texto, abrindo mão de ser o autor/usuário e passando a ser usado pela linguagem (em vez de apenas usá-la).

Com a revisão do referencial teórico, parece que é possível concluir que só a leitura é capaz de fazer isso com uma jovem e neurótica professora de Língua Portuguesa: sair da obsessão pela forma, pela estética da palavra, pelas regras e pela rigidez da gramática que, segundo os gramáticos, tudo vê, tudo sabe e em tudo governa... É, de fato, eu me rendo (e me vendo): com a literatura eu posso viajar, literalmente. Bem, mas vamos "ao trabalho, Edilaine." Este ensaio está mais para autobiográfico do que crítico... Davanti! Ocorre que, ao fechar o livro, mudo de obra e de, digamos assim, "gênero". Entre uma leitura e outra, divido meu tempo e gosto: ensaios críticos, textos científicos (leia-se "dissertações, teses ou monografias”) ou literários, mas não (nunca!) nesta mesma ordem. Saio, então, da cruel dúvida ${ }^{11}$

\footnotetext{
${ }^{9}$ Aprender pelo rumor da escritura é, como afirma Barthes (2004, p. 10), escutar o sutil rumor da linguagem, ouvir nossa própria voz. No capítulo I do Rumor, há um título lindo: ESCREVER A LEITURA. Ali Barthes nos questiona se já aconteceu de lermos levantando a cabeça (para, dentro dela, escrevermos um texto enquanto a erguemos). Ler não para escrever melhor, mas talvez para suscitar outra(s) escritura(s) possível(eis).

10 "Ler é desejar a obra, é pretender ser a obra, é recusar dobrar a obra fora de qualquer outra fala que não a própria fala da obra: o único comentário que um puro leitor, que puro se mantivesse, poderia produzir. Passar da leitura à crítica é mudar de desejo: é deixar de desejar a obra para desejar a própria linguagem. (BARTHES, 1987, p. 78).

${ }^{11}$ Cruel porque as relações que mantemos com os textos de escritura, que fazem sentido para nós, são (conforme BARTHES, 1987, p. 56) relações de indivíduo para indivíduo, de corpo a corpo.
} 
“duelar ou morrer de amor?", à moda Cervantes, e entro nas incertezas e questionamentos do, não tão jovem assim, Roland Barthes.

As obras "O prazer do texto"(1998) e "O grau zero da escritura"(1971) me trazem bons e duros questionamentos: "Quem suporta a contradição entre escrever, escrita, e escritura?". E existe diferença? Não me contaram isso antes... Por quê? Fui enganada... Por tanto tempo. É, o conhecimento pesa, muito! Estou tão confusa. Da Espanha vou para a Inglaterra e isso me faz parodiar Shakespeare, "Ser ou não ser" deveria significar "Ler ou não ler"... É melhor voltar, para evitar que toda esta empolgação vire tragédia grega.

\section{TERCEIRO GESTO - SOBRE O PRAZER ENVOLVIDO}

Barthes se aventura ao afirmar que criou uma teoria entre a linguística e a semiologia. Para ele, Babel não é mais, ou talvez nunca tenha sido, punição: é fruição pura, a tese do prazer remete a uma Babel feliz, onde o encontro de várias línguas gera o caos, mas um caos que produz, que tem efeito, que não apenas reproduz...que cria, que causa, que implica, que está imbricado. A fruição ocorre quando há gozo, isto é, quando tomamos posse das palavras, como se fossem parte de nossa fala, fazendo delas usofruto. Tal feito ocorre também na escrita. Mas então escrever com prazer assegura a fruição do leitor? Não! O escritor que, em tese, não é louco ou neurótico, é quem passa pela fruição, quando entra em contato com a escritura.

Há uma dicotomia bem definida que diz respeito ao texto, quando o escrevemos, temos que dar prova ao leitor de que ele, o texto, enquanto produção, nos deseja, nos quer. Este seria um forte indício de escritura. Daí o título da obra. "O prazer do texto" é semelhante a uma fenda insustentável entre a morte, a destruição feita através da língua ${ }^{12}$.

Fala-se em morte, pois escrever faz parte da vida, é um ensaio, uma constante luta, permanente greve, manifesto contra a morte. Se nada mais existe, exceto a língua, visto que somos rodeados por linguagem e por signos, "coisas que usamos no lugar de outras coisas", então usamos a ficção o tempo todo. Tudo é literatura ${ }^{13}$, é faz de conta. Se escrever é representar, então qual é o objetivo de descobrir a diferença entre escrever (escrita e escritura)? A escrita parece ser quase uma leitura mecânica, como um analfabeto funcional, que lê, mas não entende o que leu, que só decodifica, que não compreende, tampouco interpreta. Não, ela não é importante por isso. Ela pressupõe a escritura, que passa pela emoção, pelo devir, pela fruição, envolve o tempo à medida que o faz "estagnação". Vai além de, não apenas preenche espaço na folha, mas representa verdades, faz sentido, corresponde ao que me faz respirar, às necessidades. Escrita é o que, infelizmente ou não, eu fiz na escola, o que aprendi a fazer e o que fui treinada por anos para "ensinar", como se escrever (a escrita) fosse "ensinar uma virtude".

Não existe por trás do texto ninguém ativo (escritor) e ninguém passivo (leitor); a escritura é como o olho por onde vejo e por onde me veem. O prazer do texto ${ }^{14}$ é o momento em que meu corpo segue

\footnotetext{
${ }^{12}$ A língua pode fazer a escritura sangrar. A leitura seria a hemorragia da escrita, o lugar em que a estrutura se descontrola e de onde pode surgir o grau zero da escrita, o prazer do texto, a escritura! Abarcando esse sentido, essas possibilidades de modo não chato chegam. Defendo a bandeira do texto, porque sabemos que, conforme Barthes, é por aí que o escritor surge, aparece, nesse embate entre ele e o mundo. Com o livro em primeiro plano, tendemos a visualizar o autor. Já o texto quer a morte do autor, que vem com o nascimento do leitor, ainda com base em Barthes (2004).

${ }^{13}$ Mario Osório Marques (1997, p.139) afirma que se no texto que lê, o leitor não surpreende efeitos outros que os por ele supostos serem os pretendidos por quem o escreveu, não existe leitura, apenas decifração. O poeta pinta quadros com as palavras.

${ }^{14}$ Mario Osório Marques (1997, p.58) afirma que ao escrever a imaginação produtiva é poder ativo; (P.. 56) e que o papel da teoria no escrever não é como o de algo a ser confirmado ou negado, mas como provocação de um horizonte mais vasto, pois não há outro caminho para atingir a realidade a não ser através da imaginação.
} 
suas próprias ideias, pois não parece ter as mesmas que eu. É quase como assinar nosso atestado de total incompetência e impotência perante a linguagem e, o melhor, é como se não estivéssemos preocupados com isso! É o tal prazer, a tal fruição, a rendição ao texto, tal qual o Elogio à Loucura seria o elogio à escritura, mas não como a salvação única dos problemas na Educação, porém como uma boa alternativa para o relativismo do "reproduz, copia, imita e repete", método de ensino aplicado pela sociedade moderna, tão repercutido na escola dita tradicional.

Se somos a sociedade considerada "pós-moderna" ou se vivemos em tempos líquidos, inseridos na sociedade contemporânea, tanto faz. $\mathrm{O}$ fato é que parece ser uma jogada política ter um povo dependente, sem acesso à literatura de qualidade (ou que, quando tem acesso, não lê, não faz uso adequado da propriedade cognitiva, ou lê, mas sem se apropriar do que leu, apenas repetindo como papagaio e, o que é pior, sem concordar ou discordar do que leu). O mesmo ocorre na escrita. Somos treinados para escrever... não a escritura, a escrita. Isso não é de todo ruim, reitero, o problema é não avançar, afinal, a escola "forma" (põe em fôrma e deforma!).

Quando há talento e sobra vontade, basta derramar burocracia e enjaular os sonhos, para quebrar o encanto que é ler e escrever com propriedade ${ }^{15}$, o fascínio que é a literatura e a escritura. Ah! Isso sim é ciência, a arte da ironia. Aluno bom é o que resolve problemas, não o que cria! É o que não propõe nada, só o que aceita tudo. O que escreve sem reclamar ou o que, como protesto contra a ordem, não escreve, se nega enquanto ser e, ao negar a linguagem, aceita o sistema imposto e permite que os professores reclamem da sua péssima produção e o encham de rótulos, comparando-o, inevitavelmente, com outros colegas ditos melhores, por repetirem, copiarem e ainda dizerem que os textos são seus, com as ditas marcas de autoria tão mensuradas no processo de escrita, não de escritura. O que seria da repetência sem os fracassos e a greve da escrita?

Por que não citar também Paulo Freire? Sua obra trazia (e ainda traz) como proposta a busca pela igualdade, apostando numa educação que tem como pressuposto o diálogo, em que todos têm direito à voz e se educam mutuamente. Este diálogo reflete na condução de qualquer indivíduo a um nível crítico elevado, gerando ações em conjunto. É necessária a interatividade dos indivíduos com eles próprios, com os outros e com o mundo (conhecimentos da comunicação explorados pela Pedagogia Dialógica de Paulo Freire $\left.{ }^{16}\right)$. No que tange à associação livre entre Ricouer, Freire e Barthes, penso que tomar a palavra e não entregá-la a alguém que fale ou escreva por nós é um exercício de autonomia, sobretudo de distanciamento, apropriação e escritura. Proposta de intervenção, autoria e arte, a escrita como se as palavras fossem nossa vida (e, de fato, o são! Tudo é linguagem, só ela nos resta).

A frase (ou a forma, a escrita), rígida por natureza, seria o corpo? NÃO! Mas a escritura seria a cultura $^{17}$, ou seja, igual a mais prazer. O prazer da frase, esse sim, é cultural, mas tal fruição não obriga ao prazer. Contudo, pode haver prazer no texto, na escrita, mas este não é seguro, é frio. Já o da escritura

\footnotetext{
${ }^{15}$ Assim 'tocar' um texto, não com os olhos, mas com a escrita, abre, entre a crítica e o leitura, um abismo, o mesmo que qualquer significação abre entre o seu bordo significante e o seu bordo significado. Porque, para Barthes (1987, p. 77) "tanto do sentido que a leitura dá à obra como do significado, nada se sabe, talvez porque esse sentido, sendo o desejo, se estabelece para além do código da língua. Só a leitura ama a obra, mantém com ela uma relação de desejo".

${ }^{16} \mathrm{O}$ respeito à individualidade e à subjetividade lembra os ditos de Paulo Freire, em Pedagogia da Autonomia (1996), alertando quanto ao respeito à dignidade de cada um. $\mathrm{O}$ fracasso educacional deve-se em particular à técnicas de ensino ultrapassadas e sem conexão com o contexto social e econômico do aluno. Isso seria um imperativo ético e não um favor que podemos ou não conceber uns aos outros. A prática docente da escritura deveria ser coerente com o saber do respeito à identidade do educando. (nota dos autores)

${ }^{17}$ Mario Osório Marques (1997, p.83) afirma que a poesia não pertence a quem a fez, mas a quem ela utiliza. Na leitura estão implicados o sujeito que escreve deixando no escrito suas marcas e os sujeitos que ao lerem atualizam, dão vida ao que foi escrito. A letra mata; o espírito vivifica. A folha de papel não é apenas suporte passivo, é campo aberto à criatividade do escrever e do ler, convite e incitamento à intercomplementaridade de atos separados por um hiato de tempo, que até pode ser de séculos, como pode ser de segundos, naquele instante.
} 
é livre, nunca igual, sempre diferente da primeira vez. Tudo é fruído, jogado. A fruição pode até ser precoce, mas está imbricada com a arte, que parece compromisso. Daí o esforço de todo artista para destruir sua própria arte: entra-se para a academia ou cria-se uma profissão. Eu sempre quis trabalhar com algo que envolvesse meu hobby, a escrita, sem saber que, na verdade, eu praticava a escritura, mas fui treinada, insistentemente, por anos, para escrever, para ser hábil com a escrita. Daí a coisa só piorou...Fiz Letras, fiz especialização para Análise do Discurso e das Linguagens Midiáticas e Virtuais, cursei Linguística e faço Mestrado. Recuso o prazer da escritura, o prazer do texto... Só resta desejo e fruição. Medo. Acabo de descobrir que sou masoquista. Devo ser. Tal qual a mística do texto, como consumo... Usamos o texto como produto. E quem interpreta isso? A própria interpretação, forma de vontade que existe enquanto paixão.

O texto é tecido. Durante essa tessitura é possível escrever em voz alta. Estudei que isso seria fonologia, mas percebo que é fonética, pois sentimos as palavras, cada letra, cada forma e cada escritura, na pele, na voz, na garganta, na alma. Este seria o grau zero, o nível básico. Obviamente, Ronald Barthes percebeu que não existe literatura sem uma "moral da língua", sem a forma, sem a escrita. Mas sabe-se que a Escritura é uma opção necessária que o escritor tem ou faz entre as várias morais da língua. $\mathrm{O}$ impossível da escritura é o da própria vida ou sociedade. Daí o termo: o grau zero da escritura, que nada mais é do que não apenas comunicar ou exprimir, mas ser a dúvida, a insegurança de cair em contradição, de afirmar que não se sabe se há uma única verdade, se estamos indo na direção certa, se há, de fato, tal direção. É como impor a história e o partido que vai, aos poucos, tomando sua própria forma, sem forçar, induzir... mas sozinho, quase que intuitivamente. É como se as coisas não precisassem ser... como se elas apenas "fossem". Assim é nos textos de escritura, mas não, ao que consta, nos de escrita. Nestes as coisas não podem "apenas ser", ela "têm" que ser, precisam, necessariamente, ser.

Não existe escrita sem rótulo, contudo a escritura atravessa o olhar, o fazer e a ausência. As chamadas "escritas neutras" são o grau zero da escritura, ou "a escritura branca", como o último episódio de uma paixão ${ }^{18}$. Toda forma é um valor, pois entre língua e estilo há outra realidade: a escritura. Língua e estilo são objetos; escrever é uma função (estabelece a relação entre sociedade e criação. Ponto! Só isso. Parece muito, mas não o é. Isso é escrita, formal!). Se a palavra tem mesmo memória, então a escritura é o elo entre a liberdade e a lembrança, ainda que inconsciente.

A ponte entre a ambiguidade da mentira ficcional de um romancista e a "sinceridade precisa" de signos falsos é a escritura. O seu grau zero é poder optar, ter a opção ou de escrever uma dissertação, tese científica, por exemplo, ou escrever seu romance. Ainda que seja em prosa ou verso, sem nunca ser editado ou publicado, mas ter a opção de fazer, querer fazer e poder, tentar, enfim, fazer... Escrever. A escritura, ou princípio livre, é a ligação que acorrenta o escritor à história, que por sua vez já está acorrentada à sociedade, com signos bem claros da arte.

A literatura torna-se a utopia da linguagem... por ser "livre" aos que se aventuram. Aos demais, resta copiar, repetir, ouvir, decodificar, nunca ler, escrever, falar e produzir conhecimento de verdade. Iniciei com Dom Quixote e concluo com outro contra-herói, o leitor. Só mesmo o leitor para aceitar ${ }^{19}$ passivamente, segundo Barthes, a contradição da escrita. Se eu acredito que o autor tenha revelado a

\footnotetext{
18 "Ler é desejar a obra, é pretender ser a obra, é recusar dobrar o obra fora de qualquer outra fala que não a própria fala da obra: o único comentário que um puro leitor, que puro se mantivesse, poderia produzir. Passar da leitura à crítica é mudar de desejo: é deixar de desejar a obra para desejar a própria linguagem (BARTHES, 1987, p. 78).

${ }^{19}$ Larrossa (2004), em Linguagem e educação depois de Babel, afirma que, ao contrário da passividade, em toda escritura há um "dar a ler" do escritor (p. 22), um aprender de ouvido, assim como compreender é decifrar, é traduzir, é explicar, dar a luz, (p. 91). Segundo ele, podemos ser amantes das palavras, senti-las, amar o seu corpo, tendo a liberdade de "ler" como experiência, sem negar o nosso corpo, fabricado na escola como um problema (p.173).
} 
VERDADE com tais livros? Bem, confesso que não posso ficar livre; a formalidade da escrita prega que um ensaio crítico deva explicitar a opinião do leitor da(s) obra(s) lida(s). Portanto, Barthes pensa que fez ou criou uma teoria. Que bom!

Roland foi feliz ao afirmar muitas coisas: "a literatura como utopia da língua", a forma rígida e fechada com que a escola oprime e força à escrita, à formação de leitores ou escritores pela formatação, pela forma, pela estética, pelo estilo, não pelo conteúdo, pela liberdade, pelo prazer de escrever, de se ter o grau zero da escritura, pela escolha, pela fruição, pelo devir, pelo sentido que tal ação representa, uma vez que é na linguagem e pela linguagem que me constituo e me (des)construo, enquanto ser, como humano, situando-me comigo e com o mundo.

\title{
GESTO FINAL - LEITURAS OUTRAS
}

A escola trata de fazer os alunos aprenderem os "significados" consagrados (significado é da ordem do "já dado": imagem criada para um mundo supostamente já compreendido), mas raramente abre para a criação de novos sentidos (sentido: é da ordem da criação, das conexões que podem existir entre um fenômeno e uma consciência, em condições inéditas). Ainda de acordo com Bocca (2017),

\begin{abstract}
Apresenta Barthes uma nova visão de um mundo que contém apenas um grau muito tênue de organização. Tênue, no sentido de que tem criado "a cada vez" os objetos de que carece e os mecanismos ou formas de organizá-los. Queremos dizer que tal perspectiva insere-se no que Umberto Eco chamou de Obra aberta, isto é, de uma obra que elabora seu código (que não a precede), que o funda a partir de si mesmo, que oferece a chave de sua própria leitura. A perspectiva de Barthes passa a ser a de uma atividade que, longe de visar a descobrir estruturas, visa a construir ad infinitum novas realidades, novos simbolismos onde sua pesquisa, homologamente ao processo de produção, já é atividade produtora de formas e de significados (p.26).
\end{abstract}

Logo, basta uma simples abertura ao inaudito da linguagem, ao silêncio, ao não sabido, ao outro...e pronto! A escritura estaria presente. Mas parece muito difícil tornar a escritura acima da escrita. É mais gratificante seguir ouvindo e fomentando as vozes que reclamam: escrever é difícil, odeio Português, sou zero à esquerda em aula de redação, "a sora fala como se fosse fácil". Não, queridos leitores, não é nada fácil. Por isso retomo a importância de despertar o gosto pelas letras, o hábito de ler, o prazer do texto, o incentivo à leitura.

Nas palavras do próprio Barthes (2004), as razões ${ }^{20}$ pelas quais ele imaginava que escrever valeria a pena poderiam ser enumeradas como:

1. por necessidade de prazer que, como se sabe, não deixa de ter alguma relação com o encantamento erótico;

2. porque a escrita descentra a fala, o indivíduo, a pessoa, realiza um trabalho cuja origem é indiscernível;

3. para pôr em prática um "dom”, satisfazer uma atividade instintiva, marcar uma diferença;

4. para ser reconhecido, gratificado, amado, contestado, constatado;

5. para cumprir tarefas ideológicas ou contra-ideológicas;

6. para obedecer às injunções de uma tipologia secreta, de uma distribuição guerreira, de uma avaliação permanente;

7. para satisfazer amigos, irritar inimigos;

20 “Como escrever não é uma atividade normativa nem científica, não posso dizer por que nem para que se escreve. Posso apenas enumerar as 10 razões pelas quais imagino escrever”... (BARTHES, 1987). 
8. para contribuir para fissurar o sistema simbólico de nossa sociedade;

9. para produzir sentidos novos, ou seja, forças novas, apoderar-me das coisas de um nodo novo, abalar e modificar a subjugação dos sentidos;

10. Finalmente, como resultado da multiplicidade e da contradição deliberadas dessas razões, para burlar a ideia, o ídolo, o fetiche da Determinação Única, da Causa (causalidade e "boa causa") e credenciar assim o valor superior de uma atividade pluralista, sem causalidade, finalidade nem generalidade, como o é o próprio texto. (2004a, p. 101-102).

Em casa, na escola, em todos os lugares, dos embriões aos "jovens de 100 anos" (ou além!). Não há limites para o ócio criativo e a fruição é o insight inicial para novos projetos, sempre! O "dar a ler" ou o "ler de ouvido" barthesiano pode incitar, ainda que sem querer, à resolução de problemas ou quiçá "apenas" a leituras outras ${ }^{21}$. Mas este é sempre um ato novo, de coragem, e que obrigatoriamente depreende o envolvimento do outro que está intrínseco em mim, já que ler e escrever são atividades sociais. Como a escola é o local que permite a disseminação de saberes e a construção coletiva, o engessamento da escritura precisa dar espaço a novos diálogos e à abertura e à construção de novas poéticas $^{22}$, instauradoras e ressignificadoras de sentidos. Entre a morte e a vida está o ato criativo. E todos estes processos perpassam pela escola. Logo, a educação ainda pode (e precisa) evoluir muito. Tal mudança deve começar por nós. Barthes será, mais uma vez, o nosso guia.

\section{REFERÊNCIAS}

BACHELARD, G. Conhecimento comum e conhecimento científico. In: Tempo Brasileiro. São Paulo, 1972.

BAKHTIN, M. (VOLOCHINOV) Marxismo e filosofia da linguagem. São Paulo: Hucitec, 1986. Estética da criação verbal. $2^{a}$ ed. São Paulo: Martins Fontes, 1997.

BARTHES, R. O rumor da língua. São Paulo: Brasiliense, 2004.

Inéditos, I: teoria. São Paulo: Martins Fontes, 2004.

BAUMAN, Z. Modernidade líquida. Rio de Janeiro: Jorge Zahar Ed., 2001.

BOCCA, F. Roland Barthes: um semiólogo nômade. Revista de Filosofia Aurora, v. 15, n. 17, p. 1127, 2017.

ESCARPIT, R. A revolução do livro. Rio de Janeiro: Fundação Getulio Vargas. 1976.

GEERTZ, C. A interpretação das culturas. Rio de Janeiro: Guanabara Koogan, 1989. 2009.

O saber local: novos ensaios em antropologia interpretativa. 11. Ed. Petrópolis, RJ: Vozes,

KASTRUP, V. A invenção de si e do mundo: Uma introdução do tempo e do coletivo no estudo da cognição. Campinas: Papirus, 2009.

\footnotetext{
${ }^{21}$ Termo que remete a Mikhail Bakhtin, pressupondo que, ao ler, lemos o mundo e, portanto, não estamos sós, SOMOS. Juntos. Coletivamente. Sempre estamos rodeados, cheios, repletos e entorpecidos pelo OUTRO, por meio da alteridade e dos seus embates dialógicos.

${ }^{22}$ Uma alusão às obras de Bachelard e às suas poéticas (a poética da água, do ar, da terra, do espaço.
} 
LARROSA, J. A operação ensaio: sobre o ensaiar e o ensaiar-se no pensamento, na escrita e na vida. In: Educação e realidade, v.29, n.1, 2004.

LIPOVETSKY, G. Era do Vazio: Ensaios Sobre o Individualismo Contemporâneo. São Paulo: Manole, 2005.

JAKOBSON, R. Linguística e comunicação. São Paulo: Cultrix, 1985.

SCHOPENHAUER, A. A arte de escrever. Porto Alegre: LPM Pocket, 2000.

ZILBERMAN, R. Fim do livro, fim dos leitores? São Paulo: SENAC, 2001. 